\title{
CZECH AND SLOVAK YOUNG BROWN COALS IN ENVIRONMENTAL APPLICATIONS
}

\author{
PAVEL JANOŠ' ${ }^{1}$, JURAJ LESNÝ ${ }^{2}$, LUCIA ZÁVODSKÁ ${ }^{3}$, \\ SYLVIE KŘÍŽENECKÁ ${ }^{1}$, LUCIE HERZOGOVÁ ${ }^{1}$ \\ ${ }^{I}$ Faculty of the Environment, University of Jan Evangelista Purkyně, Králova Výšina \\ 3132/7, Usti nad Labem, CZ-400 60,Czech Republic (pavel.janos@ujep.cz) \\ ${ }^{2}$ Faculty of Natural Sciences, University of SS. Cyril and Methodius, Nám. J. Herdu 2, \\ Trnava, SK-917 01, SlovakRepublic (lesnyj@ucm.sk) \\ ${ }^{2}$ Department of Projecting\&Nuclear Safety, EKOSUR, Jaslovské Bohumice, \\ SK-919 31 Slovak Republic (zavodska@ekosur.sk)
}

\begin{abstract}
In recent time, various kinds of young brown (low-rank) coals are utilized increasingly not only as fuels, but also as valuable materials in advanced environmental applications. It should be noted in this context that significant deposits of the young brown coals can be found both in the Czech Republic as well as in Slovakia. For their effective applications e.g. in wastewater treatment or in soil remediation, the properties of the coals should be studied in more details and numerous physico-chemical characteristics should be measured. As a part of a common Czech-Slovak project, a series of various kinds of coals was collected, including North-Bohemian oxihumolites, lignite from South Moravia and several lignites from Slovakia (Baňa Zahorie). Basic properties were measured, such as acid-base titration curves, contents of main functional groups and sorption capability towards heavy metal cations $\left(\mathrm{Cu}^{2+}, \mathrm{Zn}^{2+}, \mathrm{Co}^{2+}\right)$ and some organic pollutants. The contents of humic substances - main active constituents of the young coals - were also determined. Selected environmental applications of the brown coals will be mentioned further, e.g. for the removal of metal cations from waters or in phytoremediation of contaminated soils.
\end{abstract}

Key words: lignite, oxihumolite, humic acids, metal, sorption

\section{Introduction}

Young brown coals have been frequently used to improve the soil quality for a long time. Large deposits of various kinds of young brown coals can be found in the Czech Republic (North Bohemia, South Moravia) as well as in Slovakia. Young brown coals contain large amounts of humic substances and may serve as an exogenous source of organic soil-constituents. Due to their complex-forming ability, humic acids play a crucial role in the mobility of nutrients, essential elements and heavy metals in the environment and in the bioavailability of these elements to plants. A special kind of weathered and oxidatively altered lignite from the North-Bohemian coal basin is called "oxihumolite" (VESELÁ et al., 2005). It occurs at the surfaces of lignite deposits and is characterized by a high content of humic substances, unique sorption properties and high biological activity. Similar kinds of low-rank coals from other locations are called leonardites. Because of their sorption ability towards various kinds of chemical species, they are increasingly used also in other environmental applications, such as in wastewater treatment for the removal of metal cations (LAO et al., 2005; JANOŠ et al., 2007b; MIZERA et al., 2007), hexavalent chromium (LAKATOŠ et al., 2002), ionogenic organic substances, such as synthetic dyes 
(JANOŠ et al., 2005; JANOŠ et al., 2007a), or low-polarity organic compound, e.g. phenanthrene (KALAITZIDIS et al., 2006).

To exploit successfully the unique properties of various kinds of young brown coals, numerous physico-chemical characteristics should be measured and examined in more details. The following properties of the young brown coals are measured as a part of the common Czech-Slovak project:

- Contents and elemental composition of the organic part of coals, which is important for the plant nutrition as well as for the interaction of coals with some organic pollutants (KALAITZIDIS et al., 2006).

- Contents, elemental and phase composition of the inorganic part of coals identification of the clay minerals, determination of the contents of heavy and toxic metals often present in coals, which may limit some environmental applications.

- Contents of total and extractable humic substances, as these compounds play a crucial role in soil fertility, biological activity as well as in the mobility of pollutants.

- Acid-base properties and contents of acidic functional groups, as these groups govern the mobility and bioavailability of various species in soils, metal cations in the first place.

- Radiochemical properties of coals also important for some environmental applications.

- Surface properties (surface area, pore-size distribution, etc.) that are significant for those applications where the sorption ability of the coals is exploited.

Some preliminary results of the mentioned project are presented in this contribution.

\section{Materials and methods}

Various kinds of brown coals were collected from the selected deposits in the Czech Republic and Slovakia. For the sake of comparison, also leonardite from Gascoyne (USA) was involved in the study; it is recommended as a standard/reference material by the International Humic Substances Society. The samples were air-dried in laboratory and then used for the measurements without an additional pre-treatment except of grinding and a size classification by sieving, if not specified otherwise in the respective measurement procedure. Typically, the fraction with grain sizes less than 2 $\mathrm{mm}$ was used for laboratory experiments. The coals used in this study are listed in Table 1.

The total contents of humic acids and the contents of extractable (free) humic acids in coals were determined according to the standard procedure STN ISO 5073. For the investigations of the acid-base properties of the coals and measurements of titration curves, the classical batch method of Topp and Pepper (TOPP and PEPPER, 1949) was adopted. The original method was modified as follows (JANOŠ et al., in press): Constants amounts (typically $0.25 \mathrm{~g}$ ) of the coal were weighted into the series of 100 
$\mathrm{ml} \mathrm{PE}$ bottles. Different amounts the $\mathrm{NaOH}$ solution were added to each of the bottles and mixed with different amounts of the $\mathrm{NaCl}$ solution to keep a desired constant ionic strength after adjusting to the constant volume of $50 \mathrm{ml}$. The solutions were purged with nitrogen for several minutes, the PE bottles containing the samples under a nitrogen atmosphere were closed and equilibrated for 72 hours with intermittent shaking. Then the equilibrium $\mathrm{pH}$ values were measured using a combined glass electrode.

Table 1. Young-brown coals used in the present study

\begin{tabular}{|c|c|c|}
\hline $\begin{array}{l}\text { Name of the } \\
\text { sample }\end{array}$ & Kind of coal & Deposit/Sampling site \\
\hline OX-Vršany & $\begin{array}{l}\text { oxihumolite - naturally } \\
\text { weathered young brown } \\
\text { coal }\end{array}$ & $\begin{array}{l}\text { Mining site Vršany, North-Bohemian } \\
\text { coal basin, Czech Republic }\end{array}$ \\
\hline OX-Jiří & $\begin{array}{l}\text { oxihumolite - naturally } \\
\text { weathered young brown } \\
\text { coal }\end{array}$ & $\begin{array}{l}\text { Mining site Jiří near Sokolov, North- } \\
\text { Bohemian coal basin, Czech Republic }\end{array}$ \\
\hline OX-Václav & $\begin{array}{l}\text { oxihumolite - naturally } \\
\text { weathered young brown } \\
\text { coal }\end{array}$ & $\begin{array}{l}\text { Mining site Václav near Duchcov, } \\
\text { North-Bohemian coal basin, Czech } \\
\text { Republic }\end{array}$ \\
\hline LI-Mikulčice & lignite & $\begin{array}{l}\text { Mining site Mikulčice, south } \\
\text { Moravia, Czech Republic }\end{array}$ \\
\hline Leonardit & $\begin{array}{l}\text { leonardite - naturally } \\
\text { weathered young brown } \\
\text { coal }\end{array}$ & Gascoyne, USA \\
\hline LI-Zahorie I & lignite & Mining site Zahorie, Slovakia \\
\hline LI-Zahorie II & lignite & Mining site Zahorie, Slovakia \\
\hline LI-Zahorie III & lignite & Mining site Zahorie, Slovakia \\
\hline LI-Zahorie IV & lignite & Mining site Zahorie, Slovakia \\
\hline
\end{tabular}

Equilibrium sorption experiments (sorption of metal cations) were carried out by shaking a known amount of the coal (typically $0.4 \mathrm{~g}$ ) with $50 \mathrm{ml}$ of solution of the respective metal with desired concentration (typically ranging from 0.1 to $4 \mathrm{mmol} \mathrm{dm}^{-}$ ${ }^{3}$ ) in PE bottles. The metal solution together with the sorbent was agitated in the closed PE bottle for 72 hours using a horizontal shaker with an intensity of agitation 2 rps. Then the solid phase was separated by sedimentation/centrifugation, the concentration of the metal in the solution was determined immediately by ion chromatography or ICP-OES, and the sorbed amounts were calculated.

\section{Results and discussion}

As mentioned above, humic acids (HA) represent the main active constituents of young brown coals and the content of HA is a decisive factor in potential environmental applications of the coals. Various kinds of brown coals may differ 
significantly in the contents of HA, as can be seen from Fig. 1, where the total contents of HA as well as the contents of free HA are compared. As can be seen, all the examined coals contain significant amounts of HA and extremely high contents of HA was found in oxihumolite Václav. Functional groups in HA, mainly carboxylic and phenolic groups, govern the acid-base properties of coals. Acid-base titration curves of selected coals were measured using a discontinuous batch method. According to Ritchie and Perdue (RITCHIE and PERDUE, 2003), the content of carboxylic groups was calculated from the base consumption for titration up to $\mathrm{pH} 8$, whereas the phenolic group content was calculated from the two-fold consumption for the titration between $\mathrm{pH} 8$ and 10. Examples of the determinations are listed in Table 2. It seems that the contents of functional groups may be related to the contents of HA (see a high content of carboxylic groups in oxihumolite Václav), but preliminary results do not allow to make definite conclusions.

Table 2. Contents of acidic functional groups in chosen samples of young brown coals $\left(\mathrm{mmol} \mathrm{g}^{-1}\right)$

\begin{tabular}{lcc}
\hline Name of the sample & Carboxylic groups & Phenolic groups \\
\hline OX-Jiří & 1.20 & 1.20 \\
OX-Václav & 3.90 & 2.20 \\
LI-Mikulčice & 1.45 & 2.00 \\
LI-Zahorie I & 1.50 & 3.00 \\
LI-Zahorie II & 1.55 & 2.30 \\
\hline
\end{tabular}

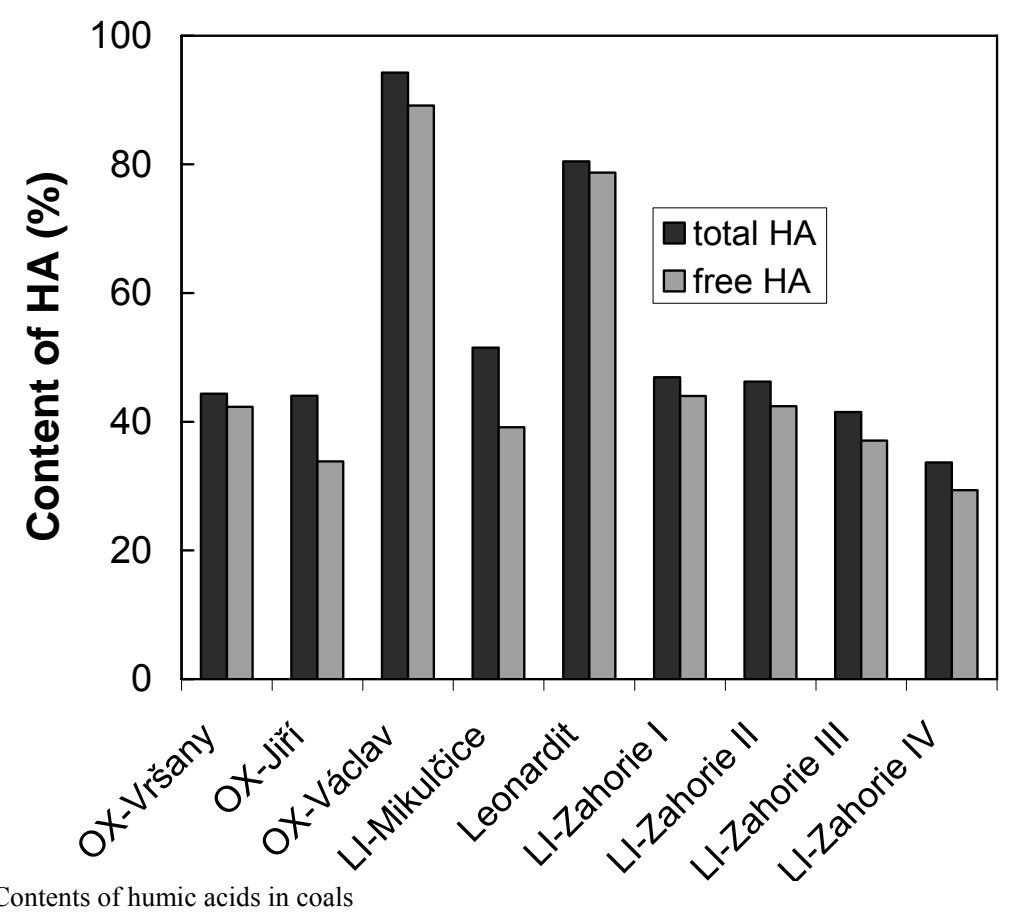

Fig. 1. Contents of humic acids in coals 
The sorption capabilities of the Czech and Slovak brown coals were studied extensively, focusing on their ability to retain heavy metal cations, in the first place. The sorption isotherms were measured for several metal cations and evaluated using various models (Langmuir, Langmuir-Freundlich) - details and model parameters can be found elsewhere (JANOŠ et al., 2007 b). For direct comparison of an ability of different coals to retain metal cations from aqueous solutions, a parameter called "nominal removal efficiency" was introduced in this work. It is defined as an efficiency of the metal removal (in \%) under given conditions. These conditions are specified as follows: Weight of the sorbent (coal) $1 \mathrm{~g}$, volume of the metal solution 50 $\mathrm{ml}$, initial metal concentration $1 \mathrm{mmol} \mathrm{dm}^{-3}$, contact time 72 hours. The removal efficiency was measured for all the above listed coals and selected metal cations $\mathrm{Cu}^{2+}, \mathrm{Zn}^{2+}, \mathrm{Co}^{2+}$.

As can be seen from Fig. 2, most of the examined coals exhibited a very high ability to retain metal cations and could be potentially used for the removal of heavy metals from wastewaters or other industrial effluents.

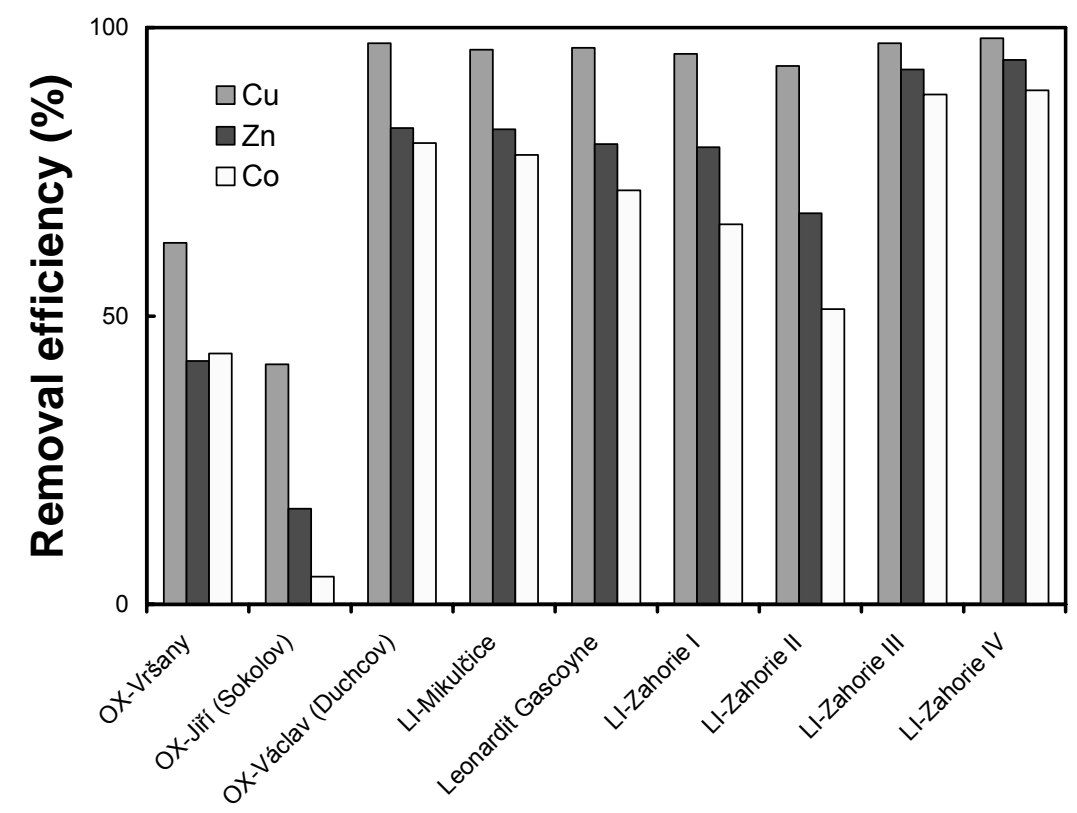

Fig. 2. Nominal removal efficiency for $\mathrm{Cu}^{2+}, \mathrm{Zn}^{2+}, \mathrm{Co}^{2+}$ ions. (Conditions: Weight of coal 1g, volume of metal solution $50 \mathrm{ml}$, initial metal concentration $1 \mathrm{mmol} \mathrm{dm}^{-3}$, contact time 72 hours)

However, the sorption ability also affects the mobility of metals and the metal bioavailability, when the coals are used in soil amendments. Further experiments consisted in an addition of coals and other HA-containing materials to soils contaminated with heavy metals. Consequently, the mobility of heavy metal in the soils was examined using a standardized extraction test (a sequential BCR test) 
(JANOŠ et al., 2004). Preliminary results showed that an addition of HA affected significantly a fractionation of heavy metals in soils.

\section{Conclusions}

The total - end free humic acid contents, the content of carboxylic - and phenolic groups as well as by the authors newly introduced parameter, the "nominal removal efficiency" towards $\mathrm{Cu}^{2+}, \mathrm{Zn}^{2+}$ and $\mathrm{Co}^{2+}$ have been determined for selected oxihumolite and lignite samples from sampling sites/deposits in Czech Republic (North Bohemia, South Moravia) and Slovakia (Mining site Zahorie). A comparison of relevant characteristics for the mentioned samples and for a well known leonardit sample (Mining site Gascoyne, USA) has been done. The results confirm the correlation between the functional group concentration and the relevant concentration of humic acids. Results of the "nominal removal efficiency" towards $\mathrm{Cu}^{2+}, \mathrm{Zn}^{2+}$ and $\mathrm{Co}^{2+}$ show a generally high ability to retain metal cations for all the examined samples with exception of the naturally weathered young brown coal from Mining site Jiř́ (near Sokolov).

\section{References}

JANOŠ, P., HERZOGOVÁ, L., REJNEK, J., HODSLAVSKÁ, J.: Assessment of heavy metals leachability from metallo-organic sorbent-iron humate-with the aid of sequential extraction test. Talanta, 62, 2004, 497-501.

JANOŠ, P., KŘÍŽENECKÁ, S, MADRONOVÁ, L.: Acid-base titration curves of solid humic acids. React. Funct. Polymers, (in press).

JANOŠ, P., MICHÁLEK, P., TUREK, L.: Sorption of ionic dyes onto untreated lowrank coal - oxihumolite: A kinetic study. Dyes Pigm., 74, 2007a, 363-370.

JANOŠ, P., SYPECKÁ, J., MLČKOVSKÁ, P., KURÁŇ, P., PILAŘOVÁ, V.: Removal of metal ions from aqueous solutions by sorption onto untreated low-rank coal (oxihumolite). Separ. Purif. Technol., 53, 2007b, 322-329.

JANOŠ, P., ŠEDIVÝ, P., RÝZNAROVÁ, M., GRÖTSCHELOVÁ, S. : Sorption of basic and acid dyes from aqueous solutions onto oxihumolite. Chemosphere, 59, 2005, 881-886.

KALAITZIDIS, S., KARAPANAGIOTI, H.K., CHRISTIANIS, K., BOUZINOS, A., ILIOPOULOU, E.: Evaluation of peat and lignite phenanthrene sorption properties in relation to coal petrography: The impact of inertinite. Inter. J. Coal Geol., 68, 2006, 30-38.

LAKATOS, J., BROWN, S.D., SNAPE, C.E.: Coals as sorbents for the removal and reduction of hexavalent chromium from aqueous waste streams. Fuel, 81, 2002, 691-698.

LAO, C., ZOLDÁN, Z., GAMISANS, X., SOLÉ, M. : Sorption of Cd(II) and Pb(II) from aqueous solutions by a low-rank coal (leonardite). Separ. Purif. Technol., 45, 2005, 79-85.

MIZERA, J., MIZEROVÁ, G., MACHOVIČ, V., BORECKÁ, L.: Sorption of cesium, cobalt and europium on low-rank coal and chitosan. Water Res., 41, 2007, 620626. 
RITCHIE, J.D., PERDUE, E.M.: Proton-binding study of standard and reference fulvic acids, humic acids, and natural organic matter. Geochim, Cosmochim. Acta, 67, 2003, 85-96.

TOPP, N.E., PEPPER, K.W.: Properties of ion exchange resins in relation to their structure. I. Titration curves. J. Chem. Soc., 1949, 3299-3303.

VESELÁ, L., KUBAL, M., KOZLER, J., INNEMANOVÁ, P.: Struktura a vlastnosti př́rodních huminových látek typu oxihumolitu. Chem. Listy, 99, 2005, 711-717. 